\title{
Okul öncesi dönem 48-66 ay çocuklarına Etkileşimli Kitap Okuma Programı'nın yazı farkındalığına etkisinin incelenmesi* $^{*}$
}

\section{The study of the effect of the interactive book reading program on 48-66 months-old preschool children's writing awareness}

\author{
Mehtap Efe ${ }^{1}$, Z.Fulya Temel $^{2}$
}

\section{Makalale Geçmişi \\ Geliş : 10 Ocak 2018 \\ Düzeltme : 10 Şubat 2018 \\ Kabul : 30 Mart 2018}

Makale Türü

Özgün Makale

\section{Article History}

Received : 10 January 2018

Revised : 10 February 2018

Accepted : 30 March 2018

Article Type

Original Article

\begin{abstract}
Öz: Araştırma düşük sosyo-kültürel özellikteki okul öncesi dönem 48-66 ay çocuklarına Etkileşimli Kitap Okuma Programı'nın yazı farkındalığına etkisinin incelenmesi amacıyla yapılmıştır. Araştırma amaçları bakımından yarı deneysel desen modeline uygun bir şekilde düzenlenmiştir. Araştırmanın çalışma grubunu 2016-2017 eğitim öğretim yılında Diyarbakır'da okul öncesi eğitime devam eden toplam 23 tipik gelişim gösteren çocuk oluşturmaktadır. Veri toplama aracı olarak araştırmacı tarafindan hazırlanan kişisel bilgi formu ve Karaman (2013) tarafından geliştirilen Erken Okuryazarlık Becerilerini Değerlendirme Aracı'nın Yazı Farkındalığı alt testi kullanılmıştır. Araştırmaya, 2016 yılının Ekim ayında her iki gruba da Karaman (2013) tarafından geliştirilen Erken Okuryazarlık Becerilerini Değerlendirme Aracı'nın Yazı Farkındalığı alt testi uygulanarak başlanmıştır. Çalışma 10 haftalık bir uygulama olup haftanın üç günü(Pazartesi-Çarşamba-Cuma) ve her uygulama yaklaşık 45 dakika olarak gerçekleştirilmiştir. Araştırmanın sonucu için, verilen programın etkiliğinin incelenmesinde ANCOVA kullanılmıştır. $\mathrm{Bu}$ araştırma kapsamında gerçekleştirilen etkileşimli kitap okuma uygulamalarının, düşük sosyokültürel özellikteki ailelere sahip çocukların ve buna ek olarak anadili eğitim dilinden farklı olan çocukların yazı farkındalığı performanslarını yüksek oranda desteklediği sonucuna ulaşılmıştır.
\end{abstract}

Anahtar Kelimeler: Erken okuryazarlık, yazı farkındalığı, etkileşimli kitap okuma, düşük sosyokültürel

\begin{abstract}
The present study was conducted to examine the effect of the Interactive Book Reading Program on 48-66 months-old preschool children's writing awareness who have low socio-cultural characteristics. The study was designed in accordance with the semi-experimental design pattern in terms of research purposes. The study group is composed of 23 preschool children showing typical developmental. It is conducted in Diyarbakır during the academic year 2016-2017. As data collection tools, Personal Information Form prepared by the researcher and Writing Awareness subtest of the Early Literacy Skills Assessment Tool which was developed by Karaman (2013) were used. The study was initiated in October 2016 by applying the Writing Awareness subtest in both groups. The study was conducted three days a week (Mondays-Wednesdays-Fridays) on a 10wk period and each application took approximately 45 minutes. In order to examine the effect of the program ANCOVA was used. It is found that, Interactive Book Reading Practices supported children's writing awareness performances with low socio-cultural characteristics at a high level. Besides it also supported children whose mother tongue was different from the language used in education.
\end{abstract}

Keywords: Early literacy, writing awareness, interactive book reading, low socio-cultural

DOI: $\underline{10.24130 / \text { eccd-jecs. } 196720182257}$

\footnotetext{
${ }^{*}$ Bu çalışma birinci yazarın Prof. Dr. Z. Fulya Temel danışmanlığında yürütülmüş olan "Düşük Sosyo-Kültürel Özellikteki Okul öncesi Dönem 48-66 Ay Çocuklarına Etkileşimli Kitap Okuma Programının Yazı Farkındalığına Etkisinin İncelenmesi”" isimli yüksek lisans tez çalışmasından yararlanılarak hazırlanmış ve 5.Uluslararası Okul Öncesi Eğitim Kongresinde "sözlü bildiri”" olarak sunulmuştur.
}

${ }^{1}$ Milli Eğitim Bakanlığı, mehtapefe99@gmail.com

${ }^{2}$ Gazi Üniversitesi, Eğitim Bilimleri Fakültesi, Temel Eğitim Bölümü Okul Öncesi Eğitimi Anabilimdalı, temel.fulya@gmail.com 


\section{SUMMARY}

\section{Introduction}

Writing awareness is one of the early literacy skills. It was mentioned for the first time by Clay in 1960 and described as: knowing the concepts related to writing, the appearance and direction of writing, knowing that it makes sense; distinguishing between picture and writing, knowing how to hold a book, how to turn its pages, and where to start reading (Bayraktar and Temel, 2015, p.64; Sarıca et al., 2014).

In the researches it is known that family and environmental factors are influential in the acquisition of literacy knowledge and skills. However, it is also known that these factors are much more important for children in the risk group and in the following years of their lives these children might experience academic, social, behavioral and emotional problems together with early literacy development (Akoğlu, Ergül and Duman, 2014; Baydık, 2003; Edwards and Willis, 2009; Erdil, 2010; Ergül, Akoğlu, Tufan and Kesiktaş, 2013; Ergül, Karaman, Akoğlu, Tufan, Sarıca and Kudret, 2014; Gül, 2007; Kandır and Koçak Tümer, 2013; Karaman, 2013; Uyanık and Kandır, 2010).

When the researchers conducted in the field are examined, it is seen that the qualified education programs have a very positive effect on the children's early literacy skills especially on those whose families come from low socio-cultural and economic environment (Akoğlu et al., 2014; Bayraktar and Temel, 2014; Büyüktaşkapu, 2012; Ergül, Akoğlu, Sarıca, Tufan and Karaman, 2015; Lonigan, Anthony, Bloomfield, Dyer and Samwel, 1999; Şahin, 2015, pp.109-122; Şimşek, 2011; Şimşek Çetin and Alisinanoğlu, 2013; Whitehurst and Lonigan, 1998). In the present study, the Interactive Book Reading Program (Akoğlu et al., 2014; Baydık, 2003; Ergül et al., 2013), which is one of the early intervention programs and contributes to preschool children's early literacy development, has been used to investigate the effect of writing awareness on children that are coming from low socio-cultural and economic environment. For this reason, the study aims to reach the following goals: providing support related to achievements and indicators given in the Pre-School Education Program of Ministry of National Education (2013a) that are created to develop early literacy skills; to find out whether interactive book reading is an important part of early literacy awareness in children or not; and if it has effect it is important to reveal this to guide educators and families. Besides, it is also important for the dissemination of the child-centered Interactive Book Reading Program, which takes place in preschool education activities and provides children active participation. 


\section{Method}

In the study, semi-experimental design with pre-test-post-test control group was used. The study group formed with 23 children from Diyarbakır during the 2016-2017 academic year. 11 of these children formed the experimental group and 12 of them formed the control group. As data collection tools, Personal Information Form prepared by the researcher and Writing Awareness subtest of the Early Literacy Skills Assessment Tool which was developed by Karaman (2013) were used. In addition, observations of the practitioner regarding children's behaviors during the Interactive Book Reading practices were used. The study was initiated in October by applying a Writig Awareness subtest of Early Literacy Skills Assessment Tool in both groups. The study was planned as a 10-wk practice. A different book was set for each week. A total of 10 books were identified with the opinions of five experts who worked in the fields of children's literature and early literacy. Five target words have been identified for each book. The target words are explained in appropriate terms and in "child friendly" terms appropriate to child's level. In addition, a sound unit determined in the book that is read every week is handled with an appropriate planned activity. The application was conducted three days a week (Mondays-Wednesdays-Fridays) and each application was approximately took 45 minutes.

After the, to find out the the effectiveness of the implemented program the collected data examined on the SPSS package program via applying ANCOVA.

\section{Results}

According to ANCOVA results that pre-test scores were taken as a common variable it is found that there was a significant difference between the post test scores of the children in the experimental and control groups $(F(1,20)=77,15, p<.01, \eta 2=0,79)$. When Eta square $(\eta 2)$ is examined, a value of 0.79 indicates that the effect of the program was high.

The corrected average of the experimental group $(11,30)$ appears to be significantly higher than the corrected average of the control group $(5,89)$.

Depending on the results of the present research, it is observed that the Interactive Book Reading Program had high effect on preschool children's writing awareness that are raised in families with low socio-cultural characteristics.

\section{Conclusion and Discussion}

It has been reported in various researches that interactive book reading support not only children's language development but also many early literacy skills such as vocabulary, writing and sound awareness's. Besides, interactive book reading is among the early intervention programs especially for 
children in the risk group (Akoğlu et al., 2014; Ergül et al., 2014, Ergül et al., 2015, Iş1koğlu Erdoğan and Akay, 2015, Işıkoğlu Erdoğan, 2016, Justice and Ezell, 2002, Lonigan et al., 1999).

In the present research it is observed that Interactive Book Reading Program applied to preschool children who are raised in families with low socio-cultural characteristics had high effect on their writing awareness (eta square $(\eta 2) ; 0,79)$. Other researches in the field support these findings.

As a result, it can be said that the interactive book reading practices carried out within the scope of the present research supported not only performances of children with lower socio-cultural characteristics in terms of writing awareness but also supported performances of those whose mother tongue were different from the language used in education ( 4 children in the experimental group and 1 child in the control group). It has also seen that interactive book reading practices contributed to children's other early literacy skills such as word awareness, alphabet knowledge, verbal skills, phonological awareness and essay writing. Although the effect was at different levels for each child, it can be said that the contribution of the Interactive Book Reading Program had high effect on children's writing awareness that are raised in families with low socio-cultural characteristics and the findings support the results of other related studies in the field. 


\section{GÍRIŞ}

Küçük çocukların okuma-yazma öğrenme sürecine formal eğitime girmeden uzun zaman önce başladığı belirtilmektedir (Bredekamp, 2015, s. 390). Formal okuma yazmayı öğrenmeden önce birçok ön becerinin kazanımının okuma yazmayı öğrenme süreci ile ilgili olduğu ve bu ön becerilerin erken okuryazarlık sürecinin bir parçası olduğu ifade edilmektedir (Karaman, 2015, s. 10; Whitehurst ve Lonigan, 1998). Erken okuryazarlığın, okuma-yazma becerilerinden bağımsız olmamakla birlikte, okuma-yazma becerilerinden daha geniş bir kapsama sahip olduğu ifade edilmektedir (Gül, 2007). Erken okuryazarlık, çocukların formal okuma-yazma öğretimine başlamadan önceki dönemlerde aile ve toplumsal çevresinin etkisiyle okuma-yazma deneyim ve birikimini edindiği, formal okuma-yazma becerilerinin ilk habercileri olarak görülen, okuma-yazma ile ilgili kazanmaları beklenen önkoşul bilgi, beceri ve tutumlarının tamamı olarak ifade edilmektedir (Baker, 2013; Çelenk, 2003; Şimşek, 2011, s. 11; Whitehurst ve Lonigan, 1998).

Erken okuryazarlık ile ilgili literatür incelendiğinde araştırmacıların, çocukların okuryazar olma sürecinde kazandıkları bilgi, beceri ve tutumları farklı şekillerde sınıflandırdıkları görülmektedir. Örneğin, Whitehurst ve Lonigan (1998)'a göre erken okuryazarlık iki farklı alandan oluşmaktadır. Bunlar içten dışa beceriler (fonolojik farkındalık, yazma ve harf-ses ilişkisi kurma becerileri, yazı farkındalığı) ve dıştan içe beceriler (sözel dil becerileri olan biçim, anlam ve kavram bilgisi) olarak isimlendirilmektedir. Cabell, Justice, Konold ve McGinty (2011) erken okuryazarlığı, sözel dil becerileri (alıcı dil ve ifade edici dil) ve kod ile ilgili beceriler (fonolojik farkındalık, yazı kavramları bilgisi, alfabe bilgisi ve isim yazma gibi beceriler) olarak sınıflandırmaktadır. Dolunay Sarıca (2016) erken okuryazarlığı sözel dil, sesbilgisel farkındalık, yazı farkındalığı, harf bilgisi ve yazılı materyale ilgi duyma olarak gruplandırmaktadır.

Erken okuryazarlık ile ilgili literatür incelendiğinde sıkça vurgu yapılan noktalardan biri, yazı kavramına ilişkin erken dönemlerde kazanılan farkındalığın, okul öncesi dönem erken okuryazarlık gelişiminde önemli bir rol oynadığı ve gelecekteki okuma-yazma yeterliliğinin güçlü bir yordayıcısı olmasının vurgulanmasıdır (Akoğlu, 2015, s. 62; Bayraktar ve Temel, 2015, s. 64; Işıtan ve Akoğlu, 2016; Şimşek Çetin ve Alisinanoğlu, 2013; Whitehurst ve Lonigan, 1998). Bu bilgiler doğrultusunda ve yapılan bu araştırma kapsamında erken okuryazarlık becerilerinden biri olan yazı farkındalığını ele aldığımızda ilk olarak 1960 yılında Clay tarafından ifade edilmektedir. Yazı farkındalığı, yazıya ilişkin kavramları bilme, 
yazının görünüşü, yönü, bir anlam ifade ettiğini bilme, yazı ile resmi ayırt etme, bir kitabın nasıl tutulacağını, sayfalarının nasıl çevrileceğini, okumaya nereden başlanılacağını bilme olarak tanımlanmaktadır (Bayraktar ve Temel, 2015, s. 64; Sarıca vd., 2014). Okuma yazmanın gelişiminde anahtar bir rol oynayan yazı farkındalığı becerisi edinen çocukların yazı dili ile konuşma dili arasındaki ilişkiyi anladıkları belirtilmektedir. Çocukların yazı dili ile konuşma dili arasındaki ilişkiyi anlamaları, okumayı öğrenmede ilk adım olarak görülmektedir (Bayraktar ve Temel, 2014). Okul öncesi dönemdeki çocuklarla yapılan bazı araştırmalarda, çocukların formal okuma-yazma öğrenimine başlayacakları dönemde kazanacakları okuma becerilerini tahmin etmede en güçlü becerilerden birinin yazı farkındalığı olduğu tespit edilmiştir (Şimşek Çetin, 2014).

Çocukların yazı farkındalığı becerilerinin gelişiminin, çevrelerinde sık sık gördükleri kelime ve işaretleri tanımaya başlamaları, çevrelerindeki yazı ve sembollere ilgi göstermeleri ile başladığı belirtilmektedir (Bayraktar ve Temel, 2015, s. 65). Okuryazarlığın kültürel bir olgu olduğu ve içinde bulunulan toplumun okuryazarlık düzeyiyle paralel olduğu ifade edilmektedir (Karaman, 2013, s. 2-25). Yaşamı düşündüğümüzde çocukların fiziksel, sosyal, çevresel vb. faktörler açısından aynı şartlarda dünyaya gelmedikleri, bazılarının risk grubunda yer aldığı görülmektedir. Ekonomik olarak yetersiz bir çevrede bulunmak, ebeveynlerin öğrenim düzeyi, gelişimsel yetersizlik, akademik programdan farklı bir dil veya lehçe konuşmak, sözel ve yazılı dil deneyimlerinin yetersiz olduğu bir çevrede bulunmanın risk faktörlerini oluşturduğu ifade edilmektedir (Baydık, 2003). Çocukların erken yaşlarda akademik beceriler kazanmasında, geliştirmesinde hem içinde bulunduğu çevre hem de çevresinde bulunan yetişkinlerle etkileşimleri etkilidir (Uyanık ve Kandır, 2010). Çocukların okuryazarlık bilgi ve becerilerinin kazanılmasında aile ve çevre faktörünün etkili olduğunun bilinmesinin yanında risk grubundaki çocuklar için bu faktörlerin çok daha önemli olduğu, erken okuryazarlık gelişimleriyle birlikte ileriki yıllarda akademik, sosyal, davranışsal ve duygusal problemleri yaşama olasılıklarının da oldukça yüksek olduğu vurgulanmaktadır (Akoğlu, Ergül ve Duman, 2014; Baydık, 2003; Edwards ve Willis, 2000; Erdil, 2010; Ergül, Akoğlu, Tufan ve Kesiktaş, 2013; Ergül, Karaman, Akoğlu, Tufan, Sarıca ve Kudret, 2014; Gül, 2007; Kandır ve Koçak Tümer, 2013; Karaman, 2013; Uyanık ve Kandır, 2010). Olası problemlerin önüne geçebilmek için okul öncesi dönemde çocukların erken okuryazarlık becerilerinin geliştirilmesine yönelik erken müdahale programlarının giderek önem kazandığı belirtilmektedir (Ergül vd., 2014). Yapılan araştırmalar incelendiğinde, özellikle düşük sosyokültürel ve ekonomik düzeydeki ailelerin çocuklarına uygulanan nitelikli eğitim 
programlarının çocukların erken okuryazarlık becerileri üzerinde oldukça olumlu etkilerinin olduğu belirtilmektedir (Akoğlu vd., 2014; Bayraktar ve Temel, 2014; Büyüktaşkapu, 2012; Ergül, Akoğlu, Sarıca, Tufan ve Karaman, 2015; Lonigan, Anthony, Bloomfield, Dyer ve Samwel, 1999; Şahin, 2015, s. 109-122; Şimşek, 2011; Şimşek Çetin ve Alisinanoğlu, 2013; Whitehurst ve Lonigan, 1998).

Çocukların dil ve birçok erken okuryazarlık becerisini (kelime dağarcığı, yazı farkındalığı, ses farkındalığı gibi) desteklediği çeşitli araştırmalarla ortaya konan ve risk grubundaki çocuklar için erken müdahale programları arasında yer aldığı belirtilen programlardan birinin Etkileşimli Kitap Okuma Programı (EKOP) olduğu ifade edilmektedir (Akoğlu vd., 2014; Baydık, 2003; Er, 2016; Ergül vd., 2014; Ergül vd., 2015; Justice ve Ezell, 2002; Lonigan vd., 1999). Etkileşimli kitap okumanın, okul öncesi dönemdeki çocukların dil ve erken okuryazarlık becerilerinin gelişimini desteklemek amacıyla, yetişkin-çocuk arasında aktif bir etkileşime dayalı birlikte kitap okuma aktivitesi olarak ilk kez Whitehurst ve arkadaşları tarafından geliştirildiği ifade edilmektedir (Ergül vd., 2013). Etkileşimli kitap okuma temelde yetişkin ve çocuğun yer değiştirdiği, yetişkinlerin rehberliğiyle çocukların öyküyü anlatan kişi konumuna geçmeyi öğrendiği, yetişkinlerin okuma sırasında çocuklara konuşmaları için firsatlar vererek, sorular sorarak, öyküyü tanımlamasına, yorumlamasına, çocukların soru sormalarına izin vererek, bilinmeyen kelimeleri açıklayarak, okuma aktivitesi boyunca öğrenilen yeni kelimeleri tekrarlayarak öğrenmelerine yardımcı olduğu, tekrarlı okumaya dayanan ve çocuğun okuma etkinliğine aktif katılımını sağlayan bir süreci ifade etmektedir (Ergül vd., 2013; Ergül vd., 2015; Justice ve Pullen, 2003; Lonigan vd., 1999).

Etkililiği birçok araştırma bulgusuyla desteklenmiş olan etkileşimli kitap okuma, kitap seçiminden öykünün son satırını okumaya kadar dikkat edilmesi gereken bir takım unsurları içermektedir (Er, 2016; Ergül vd., 2013). Etkileşimli Kitap Okuma Programı, okuma öncesi, okuma sırası ve okuma sonrası şeklinde bir uygulama planı içermektedir. Okuma öncesi etkileşimli kitap okuma adımları; gelişimsel yönden uygun bir çocuk kitabının seçilmesi, hedef kelimelerin ve sesbirimlerin belirlenmesi, açıklamaların, örneklerin ve sorulacak soruların belirlenmesi, fiziksel olarak ortamın düzenlenmesi, sınıf içinde çocukların oturma düzeninin sağlanması, kitapla tanışma, açık uçlu sorular yoluyla çocukların tahminde bulunmalarını sağlama, çocuklardan gelen cevapların yeniden düzenlenmesi şeklinde sıralanmaktadır (Akoğlu, 2016, s. 27). Okuma sırasında etkileşimli kitap okuma adımları; hedef sözcüklerin anlamlarının açıklanması, hedef sözcüklerin anlamalarının resimlerle ve ek 
materyallerle desteklenmesi, çocukların kendi yaşamları ile ilişkilendirebilecekleri örneklerin sunulması, hedef sözcüklerin anlamlarının tekrarlanması, geçmiş deneyimler ile öykünün desteklenmesi, sesbilgisel farkındalık ve yazı farkındalığg becerilerinin desteklenmesi, $5 \mathrm{~N} 1 \mathrm{~K}$ sorularının kullanılması, açık uçlu soruların sorulması, tekrarlar ve genişletmelerin kullanımı, cümle tamamlama ile sözcük dağarcığının desteklenmesi şeklinde sıralanmaktadır (Akoğlu, 2016, s. 37; Er, 2016; Whitehurst ve Lonigan, 1998). Okuma sonrasında etkileşimli kitap okuma adımları; açık uçlu sorular aracılığı ile öyküyü özetleme ve etkinlikler aracılığı ile kazanımların kalıcılığını sağlama şeklinde sıralanmaktadır (Akoğlu, 2016, s. 45; Er, 2016). Çocukların etkileşimli kitap okuma etkinliklerine aktif katılımını sağlamak, konuşmaları başlatmak ve sürdürmek için bazı temel noktalara dikkat edilmesi gerektiği ifade edilmekte; bunun için de Whitehurst ve arkadaşları tarafından CROWD (Completion - Recall - Openended - Wh-questions - Distancing) ve PEER (Prompt - Evaluate - Expand - Repeat) olarak belirlenen tekniklerin kullanılması önerilmektedir. CROWD, çocukların öyküdeki bir ifadeyi ya da cümleyi tamamlamasını istemeyi (C), çocuklara öyküde yer alan karakterler, olaylar hakkında soru sormayı (R), çocuklardan resimde anlatılan olayı tanımlaması veya daha sonra neler olabileceği ile ilgili tahminlerde bulunmasını içeren açık uçlu sorular sormayı $(O)$, resimlerdeki karakterlere, olaylara ilişkin $5 \mathrm{~N} 1 \mathrm{~K}$ soruları sormayı (W), çocuğun öyküyü kendi yaşamı ile ilişkilendirmesini istemeyi (D) içermektedir. Yetişkin davranışlarını içeren, çocuğa yapıcı dönüt verme ve cevaplarını genişletme gibi teknikleri ifade eden PEER ise konuşmayı başlatma (P), çocukların cevaplarının doğruluğunu değerlendirme (E), çocukların cevaplarını uygun kelime veya cümlelerle genişletme $(\mathrm{E})$, çocuktan düzeltilmiş veya genişletilmiş tepkileri tekrarlamasını istemeyi (R) içermektedir. CROWD ve PEER olarak ifade edilen tekniklerin öyküyü okumanın üç aşamasında (okuma öncesi-okuma esnası-okuma sonrası) ilgili yerlerde yetişkin tarafindan kullanılması gerektiği ifade edilmektedir (Dolunay Sarıca, 2016, s. 11).

Etkileşimli kitap okumanın erken okuryazarlık becerisine etkisi ile ilgili literatür incelendiğinde; Justice ve Ezell (2002) tarafından yapılan "Risk altındaki çocuklarda yazı farkındalığını artırmak için öykü kitabı okunması” adlı araştırma, düşük gelirli ailelere sahip okul öncesi dönem çocuklarına etkileşimli kitap okuma yoluyla yazı farkındalığına ve yazıya odaklanmaya etkisini incelemek amacıyla yapılmıştır. Bu araştırma sonucuna göre yazı, yazıdaki kelimeleri tanıma ve alfabe bilgisi ile ilgili bütün ölçümlerde deney grubunun kontrol grubundan daha başarılı oldukları sonucuna ulaşılmıştır. Opel, Ameer ve Aboud (2009)'un etkileşimli ve geleneksel kitap okumanın okul öncesi çağı çocuklarının kelime 
dağarcıklarına olan etkisini incelemek amacıyla yaptıkları deneysel araştırmaya göre etkileşimli kitap okunan deney grubunda yer alan çocukların kelime dağarcığında anlamlı bir artış olduğu, geleneksel kitap okunan kontrol grubunda ise herhangi bir değişimin gözlenmediği ortaya çıkmıştır. Ergül vd. (2015) tarafından yapılan “Anasınıflarında gerçekleştirilen birlikte kitap okuma etkinliklerinin "Etkileşimli Kitap Okuma” bağlamında incelenmesi" adlı araştırma sonucuna göre etkileşimli kitap okuma uygulamalarının geleneksel kitap okuma uygulamalarına göre gelişimsel olarak çok daha fazla kazanım sağladığı görülmüştür.

Günümüzde halen uygulanan MEB Okul Öncesi Eğitim Programına baktığımızda şartları elverişsiz çevrelerden ve ailelerden gelen çocuklar için ortak bir yetiştirme ortamı sağlamak ve onları ilkokula hazırlamak okul öncesi eğitimin amaçları arasında yer almaktadır (Milli Eğitim Bakanlığı [MEB], 2013a). Okul öncesi eğitimin gerekliliği ve amaçları göz önüne alındığında, erken okuryazarlık becerilerini deneyimleyebileceği bir ortamdan yoksun, bununla birlikte yazılı ve basılı materyal açısından zayıf bir ortamdan gelen çocuklar için okul öncesi eğitimin ve okul öncesi eğitim kurumlarının önemi oldukça büyüktür. Bu noktada okul öncesi öğretmenleri çocuklar için erken okuryazarlık becerilerinin desteklenmesine ve geliştirilmesine yönelik öğrenme ortamları oluşturmak ve etkili programları uygulama bakımından bu süreçteki en önemli rolü oynamaktadır. Fakat ülkemizde yapılan araştırmalara göre okul öncesi dönemde erken okuryazarlık becerilerini geliştirmeye yönelik etkinliklerin çok sınırlı olduğu ve okul öncesi öğretmenlerinin erken okuryazarlık becerilerinin desteklenmesine yönelik bilgi düzeylerinin yetersiz olduğu belirtilmektedir (Deretarla Gül ve Bal, 2006; Ergül vd., 2014). Ayrıca yapılan araştırmalarda okul öncesi eğitimde en sık gerçekleştirilen etkinliklerden biri; öğretmenler tarafından çocuklara kitap okuma etkinliği olmasına rağmen, öğretmen ve çocuklar arasında sınırlı düzeyde bir etkileşim olduğu ifade edilmektedir (Ergül vd., 2014). Buna karşın, etkileşimli kitap okumada öyküyü okuyan yetişkin ile öyküyü dinleyen çocukların zaman zaman rollerinin değiştiği, tekrarlı okumaların yapıldığı, çocukların aktif katılımının sağlandığı ifade edilmektedir (Ergül vd., 2015; Justice ve Pullen, 2003; Lonigan vd., 1999).

Bu sebeple bu araştırma, MEB Okul Öncesi Eğitimi Programında (2013a) erken okuryazarlık becerilerini geliştirmeye yönelik dil gelişimi alanında yer alan "Kazanım 9: Ses bilgisi farkındalığı gösterir. Kazanım 10: Görsel materyalleri okur. Kazanım 11: Okuma farkındalığ1 gösterir. Kazanım 12: Yazı farkındalığı gösterir.” kazanım ve göstergelerinin 
gerçekleştirilmesine yönelik destek sağlamak, çocuklarla kaliteli zaman geçirerek etkileşimli kitap okumanın erken okuryazarlığın önemli bir parçası olan yazı farkındalığına etkisinin olup olmadığını ortaya koymak; etkisi varsa verilerin eğitimcilere ve ailelere rehberlik etmesi için önemli olduğu düşünülmektedir. Ayrıca okul öncesi eğitimi etkinliklerinde yer alan, genellikle Türkçe etkinliklerinde çocuklara okunan klasik kitap okumanın yerine çocukların aktif katılımını sağlayan, çocuk merkezli Etkileşimli Kitap Okuma Programı'nın yaygınlaştırılmasına teşvik için önemli olduğu düşünülmektedir.

Tüm bu bilgiler doğrultusunda bu araştırma düşük sosyo-kültürel özellikteki okul öncesi dönem 48-66 ay çocuklarına Etkileşimli Kitap Okuma Programı'nın yazı farkındalığına etkisini incelemek amacıyla yapılmıştır.

\section{YÖNTEM}

\section{Araştırma Modeli}

$\mathrm{Bu}$ araştırma amaçları bakımından deneysel desen modeline uygun bir şekilde düzenlenmiştir. "Deneysel desenler, araştırmacıya incelediği bağımsız değişkenlere müdahale ederek bağımlı değişken üzerindeki değişimleri karşılaştırma imkanı veren, değişkenler arasındaki sebepsonuç ilişkilerini ortaya çıkarmak amacıyla kullanılan araştırma desenleri” olarak tanımlanmaktadır (Büyüköztürk, 2012; Gürbüz ve Şahin, 2014, s. 337). Gruplar random olarak seçilemediğinden bir okuldaki mevcut iki sınıf çalışma grubuna alınmıştır. Araştırmada hazır olan gruplar kullanıldığından yarı deneysel desen özelliği taşımaktadır. Araştırmada ön test-son test kontrol gruplu yarı deneysel desen kullanılmıştır.

\section{Çalışma Grubu}

Bu araştırmanın çalışma grubu, 2016-2017 eğitim öğretim yılında Diyarbakır ili merkez ilçesi Sur'da bulunan, Milli Eğitim Bakanlığına bağlı anasınıfında okul öncesi eğitime devam eden, toplam 23 tipik gelişim gösteren çocuktan oluşmaktadır. Çocukların gelişimi öğretmen beyanı olup uygulamalar sırasında aksi bir durum gözlenmemiştir. Çalışma grubunda yer alan çocuklar 48-66 ay aralığında olup 11 kişilik bir sınıf deney; 12 kişilik bir sınıf kontrol grubunu oluşturmaktadır. Kontrol grubuna herhangi bir müdahalede bulunulmamıştır.

Araştırmaya katılan ebeveynlere ait demografik özellikler Tablo 1'de sunulmuştur. 
Tablo 1. Çalışma grubunu oluşturan ebeveynlerin demografik özelliklerine göre dağılımı

\begin{tabular}{|c|c|c|c|c|c|c|c|c|c|}
\hline & & \multicolumn{4}{|c|}{ Anne } & \multicolumn{4}{|c|}{ Baba } \\
\hline & & \multicolumn{2}{|c|}{ Deney grubu } & \multicolumn{2}{|c|}{ Kontrol grubu } & \multicolumn{2}{|c|}{ Deney grubu } & \multicolumn{2}{|c|}{ Kontrol grubu } \\
\hline & & $\mathrm{n}$ & $\%$ & $\mathrm{n}$ & $\%$ & $\mathrm{n}$ & $\%$ & $\mathrm{n}$ & $\%$ \\
\hline \multirow{5}{*}{$\begin{array}{l}\text { Öğrenim } \\
\text { düzeyi }\end{array}$} & $\begin{array}{l}\text { Okuma- } \\
\text { yazma } \\
\text { bilmiyor }\end{array}$ & 4 & 36,36 & 0 & 0 & 0 & 0 & 0 & 0 \\
\hline & Okur-yazar & 2 & 18,18 & 5 & 41,67 & 1 & 9,09 & 3 & 25 \\
\hline & $\begin{array}{l}\text { İlkokul } \\
\text { mezunu }\end{array}$ & 5 & 45,46 & 5 & 41,67 & 2 & 18,18 & 4 & 33,33 \\
\hline & $\begin{array}{l}\text { İlköğretim } \\
\text { mezunu }\end{array}$ & 0 & 0 & 1 & 8,33 & 5 & 45,45 & 3 & 25 \\
\hline & Lise & 0 & 0 & 1 & 8,33 & 3 & 27,28 & 2 & 16,67 \\
\hline \multirow[t]{3}{*}{ Toplam } & & 11 & 100 & 12 & 100 & 11 & 100 & 12 & 100 \\
\hline & $21-25$ & 2 & 18,18 & 1 & 8,33 & 0 & 0 & 0 & 0 \\
\hline & $26-30$ & 5 & 45,46 & 8 & 66,67 & 1 & 9,09 & 4 & 33,33 \\
\hline \multirow[t]{3}{*}{ Yaş } & $31-35$ & 2 & 18,18 & 3 & 25 & 7 & 63,64 & 3 & 25 \\
\hline & $36-40$ & 1 & 9,09 & 0 & 0 & 2 & 18,18 & 4 & 33,33 \\
\hline & $41-45$ & 1 & 9,09 & 0 & 0 & 1 & 9,09 & 1 & 8,34 \\
\hline Toplam & & 11 & 100 & 12 & 100 & 11 & 100 & 12 & 100 \\
\hline
\end{tabular}

* “\%” anne-baba verilerinin bulundukları kategorideki yüzdeliğini ifade etmektedir.

Çalışma grubunu oluşturan ebeveynlerin demografik özelliklerine ait bilgiler Tablo 1'de gösterilmiştir. Tablo incelendiğinde çalışma grubunda yer alan deney grubundaki annelerden 4'ünün (\%36,36'sının) okuma-yazma bilmediği, 2'sinin (\%18,18'inin) okur-yazar olduğu, 5'inin (\%45,46'sının) ilkokul mezunu olduğu görülmektedir. Çalışma grubunda yer alan kontrol grubundaki annelerden 5'inin (\%41,67'sinin) okur-yazar olduğu, 5'inin (\%41,67'sinin) ilkokul mezunu olduğu, 1'inin (\%8,33'ünün) ilköğretim mezunu olduğu, 1'inin (\%8,33'ünün) lise mezunu olduğu görülmektedir. Çalışma grubunda yer alan annelerden 10'unun ilkokul mezunu olarak en fazla grubu oluşturduğu, 1'inin ilköğretim mezunu ve 1'inin lise mezunu olarak en az grubu oluşturduğu görülmektedir. Tablo 1 incelendiğinde çalışma grubunda yer alan deney grubundaki babalardan 1'inin (\%9,09'unun) okur-yazar olduğu, 2'sinin (\%18,18'inin) ilkokul mezunu, 5'inin (\%45,45'inin) ilköğretim mezunu olduğu, 3'ünün (\%27,28'inin) lise mezunu olduğu görülmektedir. Çalışma grubunda 
yer alan kontrol grubundaki babalardan 3'ünün (\%25'inin) okur-yazar olduğu, 4'ünün (\%33,33'ünün) ilkokul mezunu olduğu, 3'ünün (\%25'inin) ilköğretim mezunu olduğu, 2'sinin (\%16,67'sinin) lise mezunu olduğu görülmektedir. Çalışma grubunda yer alan babalardan 8'inin ilköğretim mezunu olarak en fazla grubu oluşturduğu, 4'ünün okur-yazar olarak en az grubu oluşturduğu görülmektedir.

Çalışma grubunu oluşturan ebeveynlerin yaş dağılımı Tablo 1'de gösterilmiştir. Tablo 1 incelendiğinde çalışma grubunu oluşturan deney grubundaki annelerden 2'sinin (\%18,18'inin) 21-25 yaş aralığında, 5'inin (\%45,46'sının) 26-30 yaş aralığında, 2'sinin (\%18,18'inin) 31-35 yaş aralığında, 1'inin (\%9,09'unun) 36-40 yaş aralığında, 1'inin (\%9,09'unun) 41-45 yaş aralığında olduğu görülmektedir. Tablo 1 incelendiğinde çalışma grubunu oluşturan kontrol grubundaki annelerden 1'inin (\%8,33'ünün) 21-25 yaş aralığında, 8'inin (\%66,67'sinin) 2630 yaş aralığında, 3'ünün (\%25'inin) 31-35 yaş aralığında olduğu görülmektedir. Çalışma grubunda yer alan annelerden 13'ünün 26-30 yaş aralığ i ile en fazla grubu oluşturduğu, 1 'inin 36-40 yaş ve 1'inin 41-45 yaş aralığı ile en az grubu oluşturdukları görülmektedir. Tablo 1 incelendiğinde çalışma grubunu oluşturan deney grubundaki babalardan 1'inin (\%9,09'unun) 26-30 yaş aralığında, 7'sinin (\%63,64'ünün) 31-35 yaş aralığında, 2'sinin (\%18,18'inin) 3640 yaş aralığında, 1'inin (\%9,09'unun) 41-45 yaş aralığında olduğu görülmektedir. Tablo 1 incelendiğinde çalışma grubunu oluşturan kontrol grubundaki babalardan 4'ünün (\%33,33'ünün) 26-30 yaş aralığında, 3'ünün (\%25'inin) 31-35 yaş aralığında, 4'ünün (\%33,33'ünün) 36-40 yaş aralığında, 1'inin (\%8,34'ünün) 41-45 yaş aralığında olduğu görülmektedir. Çalışma grubunda yer alan babalardan 10'unun 31-35 yaş aralığı ile en fazla grubu oluşturduğu, 2'sinin 41-45 yaş aralığı ile en az grubu oluşturdukları görülmektedir.

Çalışma grubunda yer alan ebeveynlerin mesleki durumlarına bakıldığında; annelerin tamamının ev hanımı olduğu, babalardan 14'ünün esnaf (pvc doğrama, demir doğrama, tesisatçı, şoför vb.), 6'sının dönemlik iş yaptıkları ve çoğu zaman işsiz oldukları, 3'ünün işçi olduğu verilerine ulaşılmıştır.

Araştırma kapsamında çalışma grubunda yer alan ailelerin evlerinde bulundurdukları kitap sayısı ile ilgili en fazla kitaba sahip olan ailenin ders kitapları ve diğer kitaplar dahil toplam 56 kitaba sahip olduğu, 6 ailenin evinde ders kitapları dışında kitap olmadığı, 5 ailenin evinde hiç kitap olmadığ verilerine ulaşılmıştır.

\section{Veri Toplama Araçları}


Veri toplama aracı olarak araştırmacı tarafından hazırlanan kişisel bilgi formu ve Karaman (2013) tarafından geliştirilen Erken Okuryazarlık Becerilerini Değerlendirme Aracı'nın Yazı Farkındalığı alt testi kullanılmıştır.

\section{Kişisel Bilgi Formu}

Kişisel Bilgi Formu, ebeveynlerin yaşı, eğitim düzeyi, mesleği, sahip oldukları çocuk sayısı, aylık geliri, evlerindeki kitap sayısı gibi bilgilerin öğrenilmesine yönelik maddeleri içermektedir. Kişisel Bilgi Formu'ndan çocuklarla ilgili temel bilgilerin elde edilmesinde, ailenin sosyo-kültürel, sosyo-ekonomik durumu ile ilgili bilgilerin elde edilmesinde yararlanılmıştır. Ayrıca etkileşimli kitap okuma uygulaması sırasında çocukların davranışlarıyla ilgili uygulayıcının gözlemlerine başvurulmuştur.

\section{Erken Okuryazarlık Becerilerini Değgerlendirme Aracı - Yazı Farkındalı̆̆ı Alt Testi}

Karaman (2013) tarafından geliştirilen Erken Okuryazarlık Becerilerini Değerlendirme Aracı beş alt test ve toplam 96 maddeden oluşmaktadır. Yazı Farkındalığı alt testi Erken Okuryazarlık Becerilerini Değerlendirme Aracı'nda yer alan ikinci alt testtir. Yazı Farkındalığı açımlayıcı faktör analizi sonucuna göre 3 faktörlü toplam 16 maddeden oluşmaktadır. Yazı farkındalığı alt testi; "Yazı Kavramları”, "Kitap Kavramları", "Harf ve Sözcük Kavramları” şeklinde isimlendirilmiştir. Yazı Farkındalığı alt testinin alt-üst \%27'lik gruplarda madde ayırt ediciliğine ilişkin t testi sonuçlarına göre maddelerin tamamının alt ve üst \%27'lik gruplarda ayırt edici olduğu sonucuna ulaşıldığı belirtilmektedir. Yazı Farkındalığının 16 maddesi ile ilgili madde güçlüğü ortalaması, p=.48, madde ayırt edicilik ortalaması, $\mathrm{p}=.31$ 'dir. Bu değerlerin, testin maddelerinin güçlük ve ayırt edicilik indekslerinin kabul edilen değerler arasında olduğu belirtilmektedir. Yazı Farkındalığı alt testinin KR-20 güvenirlik değeri 0.75 , test tekrar test güvenirliği $r=0,72$, testin iki yarı güvenirliği için hesaplanan split half değerinin 0.60 olarak bulunduğu belirtilmektedir. Yazı Farkındalığı alt testinin faktörlerinden elde edilen güvenirlik değerleri incelendiğinde; Yazı Kavramları faktörünün KR-20 değerinin 0,70, Kitap Kavramları faktörünün KR-20 değerinin 0.83, Harf ve Sözcük Kavramları faktörünün KR-20 değerinin de 0,60 olarak bulunduğu belirtilmektedir. Yazı Farkındalığı alt testinin test tekrar test güvenirliği incelendiğinde Yazı Kavramları faktörü için 0.70, Kitap Kavramları için 0.38, Harf ve Sözcük Kavramları faktörü için 0.77 olarak bulunduğu belirtilmektedir. Bu sonuçların psikolojik bir test için hesaplanan güvenirlik 
katsayısı açısından ele alındığında testin iç tutarlılığı ve test tekrar test güvenirliği açısından puanlarının yeterli olduğu şeklinde yorumlanabilir (Karaman, 2013, s. 153-165).

\section{Verilerin Toplanması}

Ön-test, uygulama ve son-test aşamalarından oluşan araştırmanın uygulamasına başlanmadan önce uygulamanın yapılacağı kurumdan, çalışma grubunu oluşturacak çocukların ailelerden ve Karaman (2013) tarafından geliştirilen Erken Okuryazarlık Becerilerini Değerlendirme Aracı'nın Yazı Farkındalığı alt testinin kullanımı için gerekli izinler alınmıştır. Araştırmaya, 2016 yılı Ekim ayında her iki gruba da Karaman (2013) tarafından geliştirilen Erken Okuryazarlık Becerilerini Değerlendirme Aracı'nın Yazı Farkındalığı alt testi uygulanarak başlanmıştır.

Çalışma 10 haftalık bir uygulama olarak planlanmıştır. Her hafta için farklı bir kitap belirlenmiştir. Etkileşimli Kitap Okuma Programı'nın uygulamasına yönelik kitapların belirlenmesinde çocuk edebiyatı ve erken okuryazarlık konularında çalışan beş uzmandan görüş alınarak toplam 10 kitap belirlenmiştir. Uygulama için kitaplar belirlenirken kitapların biçim ve içerik özellikleri açısından çocukların yaş ve gelişimlerine uygun olmasına, yazı farkındalığı becerilerini destekleyici kitap özellikleri (kitabın başlığı, yazarın adı, resimleyenin adı açık ve anlaşılır bir şekilde diğer yazılardan ayrılmıştır / bazı sayfalarda bir sözcük birden fazla kez tekrar edilmiştir / metin içinde nokta, virgül, soru işareti ve ünlem yer almaktadır / yazım hatası, noktalama hatası bulunmamaktadır vb. (Akoğlu, 2016, s. 29)) taşımasına dikkat edilmiştir.

Etkileşimli Kitap Okuma Programı'nın öğretimsel hedeflerini oluşturmak üzere uygulamada kullanılacak kitaplar için öykü kitaplarının teması ve çocukların düzeyi dikkate alınarak her kitap için beş hedef kelime (baykuş, kemirmek, çırpınmak, sıyırmak vb.) ve bir sesbirim belirlenmiştir. Hedef kelimeler uygun görsellerle ve çocukların seviyesine uygun çocuk dostu terim ve ifadeler kullanılarak anlatılmıştır. Sesbirimler, MEB’e bağlı ilkokulda görev yapan deneyimli iki sınıf öğretmeninden seslerin doğru çıkarılışı, dikkat edilmesi gereken noktalar vb. bilgiler edinildikten sonra belirlenmiştir. Her hafta okunan kitapta belirlenen bir sesbirim planlanan uygun bir etkinlikle ele alınmıştır. Uygulama haftanın üç günü (PazartesiÇarşamba-Cuma) ve her uygulama yaklaşık 45 dakika olarak gerçekleştirilmiştir. Deney grubundaki Etkileşimli Kitap Okuma Programı uygulayıcı tarafından gerçekleştirilmiştir. Kontrol grubuna herhangi bir müdahalede bulunulmayıp sınıf öğretmenleri tarafından okul 
öncesi eğitimi programına bağlı olarak Türkçe etkinliklerine devam edilmiştir. Çalışma grubunda yer alan çocuklara uygulama bittikten sonra son test uygulanmıştır.

Uygulamaya başlamadan önce deney grubuna alınan çocukların ailelerine, yapılacak araştırma uygulaması hakkında bilgi vermek için seminer gerçekleştirilmiştir. Deney grubundaki çocukların aileleri telefonla aranarak ve eve davetiye gönderilerek seminere çağırılmıştır. Seminerde, yapılacak olan araştırmanın önemi, amacı, kullanılacak yöntemteknikler ile ilgili bilgi verilmiştir. Çalışma grubunda yer alan çocuklara aileleri herhangi bir müdahalede bulunmamıştır. Araştırma uygulaması bittikten sonra çalışma grubunda yer alan ailelere etkileşimli kitap okuma ve Milli Eğitim Bakanlı̆ğ Temel Ĕgitim Genel Müdürlüğü tarafından yayınlanan Okul Öncesi Eğitim Programı ile Bütünleştirilmiş Aile Destek Eğitim Rehberinde (OBADER) (MEB, 2013b) yer alan "Resimli Çocuk Kitapları” başlıklı bölümden yararlanılarak bir seminer daha gerçekleştirilmiştir. Etkileşimli kitap okuma ve resimli çocuk kitapları ile ilgili seminerdeki amaç, katılımcıları çocukların gelişimlerinde önemli bir yeri olan resimli çocuk kitapları ve etkileşimli kitap okumanın önemi konusunda bilgilendirmek, farkındalık kazandırmak ve günlük yaşamla ilişkilendirmelerini sağlamaktır. İlgili seminerde ele alınan konular; resimli kitapların çocukların gelişimlerine etkileri, resimli çocuk kitaplarının genel özellikleri, yaşlara göre resimli çocuk kitaplarının özellikleri, kitap okurken dikkat edilecek noktalar, öyküler, bilmeceler, şiirler, tekerlemeler ve parmak oyunlarının çocukların gelişimlerine etkileri, etkileşimli kitap okumanın önemi, etkileşimli kitap okurken dikkat edilecek noktalar şeklinde planlanmıştır (MEB, 2013b, s. 60-71).

\section{Verilerin Analizi}

Veriler toplandıktan sonra SPSS (Statistical Package for Social Sciences) paket programına girilmiştir. Verilen programın etkililiğinin incelenmesinde Kovaryans Analizi (ANCOVA) kullanılmıştır. ANCOVA, "bir araştırmada etkisi sınanan bağımsız değişkenin dışında bağımlı değişken ile ilişkisi bulunan ve ortak değişken olarak isimlendirilen bir başka değişkenin ya da değişkenlerin istatistiksel olarak kontrol edilmesini sağlayarak, gruplar arası karşılaştırma olanağ1 veren güçlü bir teknik” olarak ifade edilmektedir (Büyüköztürk, 2014, s. 47).

ANCOVA için öncelikle her alt grupta (deney ve kontrol gruplarında) dağılımların normalliği, gruplar arasında varyansların homojenliği ve regresyon eğilimlerinin eşitliği varsayımları test edilmiştir. Bu varsayımlar sağlandığı için ANCOVA ile verilerin analizi yapılmıştır. 


\section{BULGULAR}

Düşük sosyo-kültürel özellikteki ailelerde yetişen ve bir okul öncesi eğitim kurumuna devam eden çocuklara uygulanan Etkileşimli Kitap Okuma Programı'nın yazı farkındalığına etkisi var midir?

Bu probleminin analizi için ANCOVA yapılmasına karar verilmiştir.

ANCOVA yapılmadan önce analizin gereklerinin yerine gelip gelmediği test edilmiştir. ANCOVA'nın en önemli gereklerinden birisi dağılımın normalliğidir. Dağılımın normalliği Shapiro-Wilk testi $(\alpha=.05)$ ile incelenmiştir.

Tablo 2. Yazı farkındalı̆̆ı ön test-son testlere ait normallik testi sonuçları

\begin{tabular}{lllll}
\hline & \multirow{2}{*}{ Grup } & Shapiro-Wilk & & \\
\cline { 2 - 5 } & & Değer & Sd & P \\
\hline \multirow{2}{*}{ Ön_test } & Deney &, 949 & 11 &, 634 \\
\cline { 2 - 5 } & Kontrol &, 910 & 12 &, 213 \\
\hline \multirow{2}{*}{ Son_test } & Deney &, 947 & 11 &, 609 \\
\cline { 2 - 5 } & Kontrol &, 873 & 12 &, 071 \\
\hline
\end{tabular}

Tablo 2 incelendiğinde analiz sonucunda deney ve kontrol gruplarının hem ön hem de son testlerinin dağılımının normal dağılımdan anlamlı olarak farklılaşmadığı görülmektedir(p>.05).

ANCOVA'da bir başka önemli gerek de ön test-son test verilerinin regresyon eğimlerinin eşit olmasıdır. Buna ilişkin regresyon eğimlerinin eşitliği test edilmiştir.

Tablo 3. Regresyon eğilimlerinin eşitliği sonuçları

\begin{tabular}{|c|c|c|c|c|c|}
\hline \multirow[t]{2}{*}{ Varyansın kaynağı } & Kareler & \multirow[t]{2}{*}{$\mathrm{Sd}$} & \multirow[t]{2}{*}{ Kareler ortalaması } & \multirow[t]{2}{*}{$\mathrm{F}$} & \multirow[t]{2}{*}{$\mathrm{P}$} \\
\hline & Toplamı & & & & \\
\hline Öntest & 61,74 & 1 & 61,743 & 27,34 & 0,000 \\
\hline Grup*Ön test & 0,01 & 1 & 0,006 & 0,00 & 0,959 \\
\hline Hata & 42,91 & 19 & 2,258 & & \\
\hline Düzeltilmiş toplam & 104,66 & 21 & & & \\
\hline
\end{tabular}

Tablo 3 incelendiğinde grup ve ön testin ortak etkisinin anlamlı olmadığı görülmektedir ( $p>.05)$. Regresyon eğimlerinin eşitliği için beklenen değer de sonucun anlamlı olmaması şeklindedir. Bu nedenle regresyon eğimlerinin eşitliği de sağlanmış durumdadır. 
$\mathrm{Bu}$ bilgiler doğrultusunda ANCOVA'nın yapılabileceği görülmüş ve analiz sonuçları aşağıdaki gibi elde edilmiştir.

Tablo 4. Yazı farkındalı̆̆ ön - test puanlarına göre düzeltilmişson - test puanlarının deney - kontrol gruplarına göre ANCOVA sonuçları

\begin{tabular}{|c|c|c|c|c|c|c|}
\hline \multirow[t]{2}{*}{ Varyansın kaynağı } & Kareler & \multirow[t]{2}{*}{$\mathrm{Sd}$} & \multirow[t]{2}{*}{ Kareler ortalaması } & \multirow[t]{2}{*}{$\mathrm{F}$} & \multirow[t]{2}{*}{$\mathrm{P}$} & \multirow[t]{2}{*}{$\eta^{2}$} \\
\hline & Toplamı & & & & & \\
\hline Öntest & 76,48 & 1 & 76,48 & 35,64 & 0,000 & 0,641 \\
\hline Grup & 165,55 & 1 & 165,55 & 77,15 & 0,000 & 0,794 \\
\hline Hata & 42,91 & 20 & 2,15 & & & \\
\hline Düzeltilmiș toplam & 284,94 & 22 & & & & \\
\hline
\end{tabular}

Ön test puanlarının ortak değişken olarak alındığı ANCOVA sonuçlarına göre, deney ve kontrol grubundaki çocukların son test puanları arasında anlamlı bir farkın olduğu bulunmuştur $\left(F(1,20)=77,15, p<.01 ; \eta^{2}=0,79\right)$. Eta kare $\left(\eta^{2}\right)$ incelendiğinde, 0,79 çıkan değer, verilen eğitimin etkililiğinin yüksek olduğunu göstermektedir.

Ön test puanlarına göre düzeltilmiş son test puan ortalamaları Tablo 5'te verilmiştir.

Tablo 5. Deney-kontrol gruplarının ön- test puanlarına göre düzeltilmiş son- test ortalamaları

\section{Düzeltilmiş}

Grup N Ortalama D-K

Ortalama

\begin{tabular}{lllll}
\hline Deney & 11 & 11,55 & 11,30 & 5,41 \\
\hline Kontrol & 12 & 5,67 & 5,89 & -- \\
\hline
\end{tabular}

Tablo 5 incelendiğinde deney grubu düzeltilmiş ortalamasının $(11,30)$ kontrol grubu düzeltilmiş ortalamasından $(5,89)$ anlamlı olarak daha yüksek olduğu görülmektedir. 


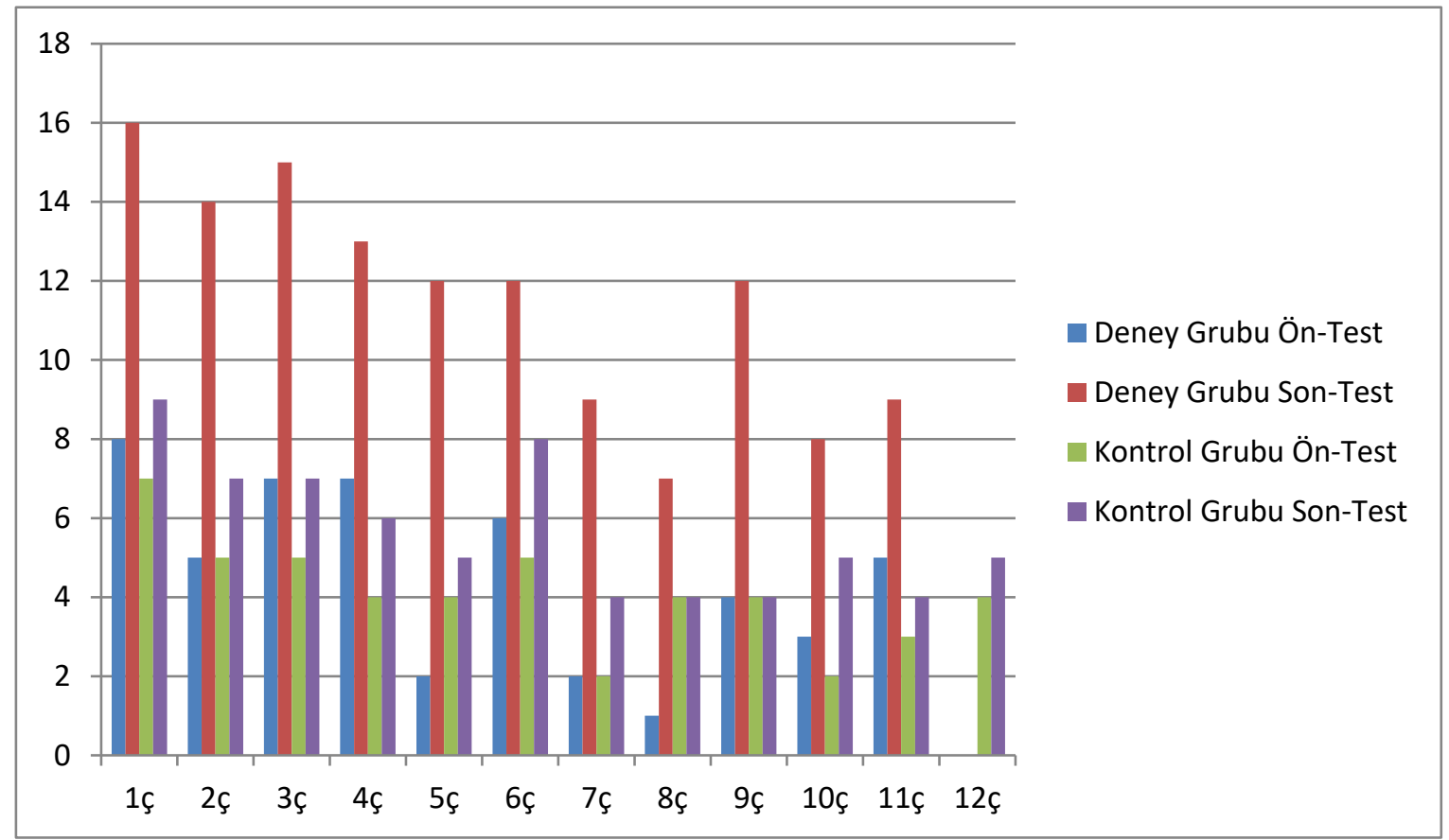

Şekil 1. Çalışma Grubunu Oluşturan Çocukların Yazı Farkındalığı Ön Test-Son Test Sonuçlarının Gösterimi

$\mathrm{Bu}$ araştırmada elde edilen sonuçlara bakıldığında düşük sosyo-kültürel özellikteki ailelerde yetişen ve bir okul öncesi eğitim kurumuna devam eden çocuklara uygulanan Etkileşimli Kitap Okuma Programı'nın yazı farkındalığına etkisinin yüksek olduğu gözlenmektedir.

\section{SONUÇ VE TARTIŞMA}

Araştırmada, düşük sosyo-kültürel özellikteki okul öncesi dönem 48-66 ay çocuklarına Etkileşimli Kitap Okuma Programı'nın çocukların yazı farkındalığına etkisinin incelenmesi amaçlanmıştır.

Araştırma kapsamında ilk olarak Şekil 1 incelendiğinde, düşük sosyo-kültürel özellikteki okul öncesi dönem 48-66 ay çocuklarının ön-test sonuçlarına bakıldığında yazı farkındalığı düzeylerinin düşük olduğu bulgusuna ulaşılmıştır. Çalışma grubunda yer alan çocukların öntest sonuçları için Şekil 1 incelendiğinde 16 maddelik yazı farkındalığı testinden ön-testte deney grubunda en yüksek puanı alan çocuğun 8 puan, kontrol grubunda en yüksek puanı alan çocuğun 7 puan aldığı; deney grubunda en düşük puanı alan çocuğun 1 puan, kontrol grubunda en düşük puanı alan iki çocuğun olduğu ve bu çocukların 2 puan aldıkları görülmektedir. 
Okuryazarlık becerilerinin gelişiminin, çocuğun bulunduğu ortamdan ayrı düşünmemek gerektiği, çocukların erken okuryazarlık becerilerinin gelişiminin sosyo-kültürel değişim sınırları içerisinde giderek önem kazandığı ifade edilmektedir (Şahin, 2015, s. 108). Aram ve Levin (2001) tarafından yapılan araştırmada çocukların gelişen okuryazarlık ve yazma becerileri ile sosyo-kültürel durumları (ailenin sosyo-ekonomik düzeyi, annenin okumayazma durumu, evdeki okuryazarlık ile ilgili araçlar, anne-çocuk etkileşimi) arasında ilişki olduğu belirtilmektedir. Yıldız, Ataş, Aktaş, Yekeler ve Dönmez (2015) tarafından yapılan araştırmada çocukların yazı algısı yaş, cinsiyet ve sosyo-ekonomik düzeye göre incelenmiştir. Araştırmanın sonuçlarına göre, sosyo-ekonomik düzeyin çocukların yazı algısını ve yazıyı konumlandırmasını etkilediği görülmektedir. Okul öncesi dönemin okuryazarlık anlamında zengin deneyimlerin yer aldığı bir dönem olmasına karşın sosyo-kültürel açıdan dezavantajlı çocukların evlerinde okuryazarlık etkinliklerinden yoksun kaldıkları (Şahin, 2015, s. 107), düşük sosyo-ekonomik ve kültürel seviyedeki ailelerin imkanlarının kısıtlı olmasının çocuklarının eğitim desteklerini olumsuz anlamda etkiledikleri, okuryazarlık anlamında daha az etkileşimde bulundukları ve okuryazarlık ile ilgili becerilerini destekleyici aktivitelere daha az yer verdikleri ifade edilmektedir (Baykan vd., 1995; Özbek Ayaz, 2015). Bu araştırma kapsamında çalışma grubunda yer alan çocukların yazı farkındalığı düzeylerinin düşük olmasında; evdeki okuryazarlık ortamlarının, ebeveyn desteğinin yoksunluğunun, aile bireylerinin eğitim düzeylerinin, çocukların yazılı-basılı materyallerden yoksun kalmalarının vb. etkisinin (Baykan vd., 1995) olabileceği düşünülmektedir. Bununla birlikte diğer araştırma bulguları da bu sonucu desteklemektedir.

Düşük sosyo-kültürel özellikteki okul öncesi dönem 48-66 ay çocuklarına Etkileşimli Kitap Okuma Programı'nın yazı farkındalığına etkisinin incelenmesi kapsamında ikinci olarak, Tablo 4'teki ANCOVA sonuçlarına bakıldığında deney ve kontrol grubundaki çocukların son test puanları arasında anlamlı bir farkın olduğu bulunmuştur $(\mathrm{F}(1,20)=77,15, \mathrm{p}<.01$; $\left.\eta^{2}=0,79\right)$. Eta kare $\left(\eta^{2}\right)$ incelendiğinde, 0,79 çıkan değer, uygulanan Etkileşimli Kitap Okuma Programı'nın etkililiğinin yüksek olduğunu göstermiştir.

Ergül vd. (2013) tarafından yapılan “ 5-6 yaş çocukların erken okuryazarlık becerilerinin geliştirilmesine yönelik Etkileşimli Kitap Okuma Programı'nın etkililiğinin incelenmesi” adlı projede, okul öncesi dönemde düşük sosyo-ekonomik yetersizlikleri nedeniyle risk altında bulunan çocukların erken okuryazarlık becerilerinin geliştirilmesine yönelik bir müdahale programı olarak "Etkileşimli Kitap Okuma(EKO)" uygulamalarının etkililiği araştırılmıştır. 
Analiz sonuçları, Etkileşimli Kitap Okuma uygulamalarının genel olarak çocukların ifade edici dil becerileri, yazı farkındalığı, sözcük ve anlam bilgisi ile sesbilgisel farkındalık becerileri üzerinde etkili olduğunu göstermiştir. Sonrasında yapılan izleme çalışmalarında ise Etkileşimli Kitap Okuma uygulamalarına katılan çocukların uygulamalara katılmayan akranlarına göre okuma ve okuduğunu anlama becerilerinde daha yüksek performans gösterdikleri bulunmuştur. Çalışmadan elde edilen bulgular, alt sosyo-ekonomik düzey nedeniyle risk grubunda değerlendirilen çocuklara okul öncesi dönemde uygulanan Etkileşimli Kitap Okuma Programı'nın kısa dönemde dil ve erken okuryazarlık becerileri, uzun dönemde ise okuma ve okuduğunu anlama becerileri üzerinde etkili olduğunu göstermiştir.

Evans, Williamson ve Pursoo (2008) “Okul öncesi çocuklarının etkileşimli kitap okuma boyunca yazıya ilgisine yönelik yaptıkları çalışmalarında, 3-5 yaşlarındaki çocukların etkileşimli kitap okuma boyunca yazıya olan dikkatlerini, yaş, bireysel farklılıklar ve yetişkinlerin kelimeleri işaret etmelerinin etkisi değişkenlerine göre incelemişlerdir. Araştırmanın sonucunda yetişkinlerin kelimeleri işaret etmelerinin, çocukların kitaba bakma sürelerini arttırdığı gözlenmiştir.

Alanyazın incelendiğinde etkileşimli kitap okumanın çocukların dil gelişimini ve birçok erken okuryazarlık becerisini desteklediği (kelime dağarcığ etkileşimli kitap okumanın özellikle risk grubundaki çocuklar için erken müdahale programı arasında yer aldığı belirtilmektedir (Akoğlu vd., 2014; Baydık, 2003; Er, 2016; Ergül vd., 2014; Ergül vd., 2015; Justice veEzell, 2002; Lonigan vd., 1999).

Düşük sosyo-kültürel özellikteki okul öncesi dönem 48-66 ay çocuklarına Etkileşimli Kitap Okuma Programı'nın yazı farkındalığına etkisinin incelenmesi kapsamında son olarak, deney grubunda yer alan 11 çocuktan 4'ünün (Ç7, Ç8, Ç9, Ç10), kontrol grubunda yer alan 12 çocuktan 1'inin (Ç7) anadilinin eğitim dilinden farklı olduğu, okul öncesi eğitime başlarken Türkçe konuşamadıkları bulgularına ulaşılmıştır. Şekil 1 incelendiğinde, deney grubunda yer alan Ç7, Ç8, Ç9, Ç10’un yazı farkındalığı düzeylerinde artış olduğu görülmektedir. Bununla birlikte etkileşimli kitap okuma uygulamaları sırasında ele alınan hedef kelimelerde, anadili eğitim dili ile aynı olan çocukların bu kelimeleri ve anlamlarını daha çabuk kavradıkları, günlük yaşamda daha sık kullandıkları gözlemlenirken anadili eğitim dilinden farklı olan çocukların kelimelerin anlamlarını kavramakta zorlandıkları, günlük yaşamda bu kelimeleri çok az kullandıkları, cümle kurarken bazı kelimeleri anadilinde bazı kelimeleri Türkçe 
kullandıkları gözlenmiştir. Okul öncesi eğitim programının da etkisiyle çocukların Türkçe konuşmayı çabuk öğrendikleri bununla beraber cümle kurarken iki dili de kullanmakta oldukları gözlenmiştir. Yapılan bir araştırmada Yazıcı ve Temel (2011) iki dilli çocukların her iki dilde de yarım dillilik olgusuyla karşı karşıya kaldıkları, iki dilli çocukların altı yaşına gelmelerine rağmen ne anadillerinde ne de ikinci dilde tek dilli çocukların ulaştığı dil ve düşünce düzeyine ulaşamadıkları, konuşulan dili anlamanın ve bilmenin ileriki dönemde okuma-yazma dilinin kavranmasında önemli olduğu, bunun akademik başarıyı da etkilediğini ifade etmektedirler. Araştırma grubunda yer alan çocukların da kelimeleri anlamakta, cümle kurmakta zorlanmalarının nedeninin hem anadilinin eğitim dilinden farklı olmasından hem de evde erken okuryazarlık materyallerinden, yetişkin rehberliğinden yoksun kaldıklarından kaynaklandığg düşünülmektedir.

Okul öncesi eğitimin ve okul öncesi eğitim kurumlarında uygulanan destekleyici nitelikte kullanılan öğretim yöntemlerinin, etkin öğrenme deneyimleri sağlayan etkinliklerin, çocukların dil ve sözcük dağarcığının gelişiminde önemli olduğu belirtilmektedir (Şimşek Bekir ve Temel, 2006). Etkileşimli kitap okumanın çocukların dil, erken okuryazarlık becerilerinin gelişimi ve sözcük bilgilerinin desteklenmesi açısından önemli bir yere sahip olduğu, bir öyküyü dinlemeden önce kelimelerle ilgili olarak yapılacak olan bazı açıklamaların çocukların kelime öğrenmelerine ciddi anlamda katkı sağladığı, kelime öğretiminin çocuğun bilgileri organize etmesinde önemli bir araç olduğu, anlatılanların derinlemesine anlaşılmasını sağlamasına, ileride okuduğunu anlamasındaki başarısının artmasına katkı sağladığı belirtmektedir (Bay, 2014; International Reading Association [IRA] ve National Association for the Education of Young Children [NAEYC], 1998; Şahin, 2015, s. 11). Etkileşimli kitap okuma sırasında çocuklara sorular sorulması, çocukların sordukları soruların cevaplandırılması, çocukların aktif katılımının gerçekleşmesi için teşvik edilmesinin daha fazla öğrenmeyi sağladığı ifade edilmektedir (Whitehurst ve Lonigan, 1998). Tekrarlı okumaların çocukların anlam oluşturma sürecine, kavramsal becerileri deneyimlemesine, tüm öykülerdeki genel olarak bulunan örüntüleri (hikayenin öğelerini) öğrenmelerine, olayları mantıksal bir sıraya koymayı öğrenmelerine, sözel dil becerilerinin gelişmesine, yazı dilini anlamalarına yardımcı olduğu ve çocukların farklı türlerin yapılandırılma şeklini tanımasını sağlamanın yanı sıra, metnin dilini daha da güçlendirdiği ifade edilmektedir (Bayraktar, 2013, s.35-36; Er, 2016; IRA ve NAEYC, 1998). Pappas (1991) yaptı̆̆ bir çalışmada, bir hikayeye birden fazla kez maruz kalma aracılığı ile çocukların hikayeyi nakletme şekillerinin giderek zenginleştiği, kitabın dili ve yazarın mesajı hakkındaki bildiklerini yaşamlarına entegre 
ettiklerini ortaya koymuştur. $\mathrm{Bu}$ sebeple, kelime ve anlama gelişimi ile ilgili olarak, etkileşimli kitap okumanın çok yararlı olduğu görülmektedir (IRA ve NAEYC, 1998). Ailede veya okul öncesi eğitim kurumunda kitap okuma etkinliklerine katılmış çocukların, formal eğitime, yazı farkındalığını kazanarak başladıkları; bir kitaptaki yazının nereden okunacağını, yazıların soldan-sağa, yukarıdan aşağıya doğru olmak üzere okunduğunu, yazı dili ile konuşma dili arasında bir bağ olduğunu bilerek başladıkları ifade edilmektedir (Akyol ve Duran, 2010). Okul öncesi dönemde kitaplarla tanışan çocukların, okuma-yazmaya doğal bir süreç içerisinde katılırken, okul öncesi dönemde kitapla tanışmamış çocukların okuma yazmaya karşı olumsuz tavır takındıkları, yaşam boyu sosyal ve ekonomik anlamda risklerle karşı karşıya kaldıkları belirtilmektedir (Lonigan, 2006). Bu açıdan araştırma bulgularını ele aldığımızda formal eğitime başlayacak olan risk grubundaki çocukların, okuryazarlık becerileri açısından dezavantajlı oldukları ve bunun olumsuz etkilerinin en aza indirilebilmesi için okul öncesi eğitim kurumlarında gerçekleştirilecek olan özellikle kitap okuma etkinliklerinin öneminin arttığı düşünülmektedir.

Erken okuryazarlık becerilerinin desteklenmesine ve geliştirilmesine yönelik öğrenme ortamları oluşturmak ve etkili programları uygulama bakımından bu süreçteki en önemli rolün okul öncesi öğretmenlerine düştüğü ifade edilmektedir. Fakat ülkemizde yapılan araştırmalara göre okul öncesi dönemde erken okuryazarlık becerilerini geliştirmeye yönelik etkinliklerin okul öncesi eğitim sınıflarında çok sınırlı olduğu ve okul öncesi öğretmenlerinin erken okuryazarlık becerilerinin desteklenmesine yönelik bilgi düzeylerinin yetersiz olduğu ifade edilmektedir (Deretarla Gül ve Bal, 2006; Ergül vd., 2014). Bu noktada okul öncesi öğretmenlerine, erken okuryazarlık becerilerine ilişkin bilgilerini artırmak amacıyla ve Etkileşimli Kitap Okuma Programı ile ilgili hizmet içi eğitim programları düzenlenmesi, MEB Okul Öncesi Eğitim Programında yer alan erken okuryazarlık becerileri ile ilgili kazanım ve göstergeler için alandaki öğretmenlerin bilgi alış verişini sağlayacak bir ağ oluşturulup farklı sosyo-ekonomik ve kültürel çevrelere uygun etkinlikler geliştirilmesi, okul öncesi öğretmenleri yoluyla ebeveynlere, erken okuryazarlık becerilerinin geliştirilmesine, etkileşimli kitap okuma uygulamasına yönelik aile katılımı programları düzenlenmesi önerilmektedir. Bu araştırma düşük sosyo-kültürel özellikteki okul öncesi dönem 48-66 ay çocuklarına Etkileşimli Kitap Okuma Programı'nın yazı farkındalığına etkisini incelenmeye odaklanmıştır, bu kapsamda araştırmanın daha fazla katılımcıyla ve farklı gruplarla yapılmasının, Etkileşimli Kitap Okuma Programı ile klasik kitap okumanın formal eğitime 
etkisini karşılaştırmak amacıyla boylamsal bir araştırma yapılmasının yaralı olacağı düşünülmektedir.

\section{KAYNAKÇA}

Akoğlu, G., Ergül, C. ve Duman, Y. (2014). Etkileşimli kitap okuma: korunmaya muhtaç çocukların alıcı ve ifade edici dil becerilerine etkileri. İlkögretim Online, 13(2), 622639.

Akoğlu, G. (2015). Okul öncesi dönemde dil gelişimi ve erken okuryazarlık. İçinde F. Turan \& A. İ. Yükselen (Ed.), Çocuk gelişimi 2 okulöncesi döneminde gelişim (s.53-72). Ankara: Hedef CS.

Akoğlu, G. (2016). Etkileşimli kitap okuma programı (EKOP): uygulama adımları. İçinde C. Ergül (Ed.), Dil ve erken okuryazarlık becerilerinin geliştirilmesine yönelik etkileşimli kitap okuma programı (EKOP) (s.25-53). Ankara: Hedef CS.

Akyol, T. ve Duran, E. (2010). Ana sınıfında yazıya hazırlık eğitimi almanın ilköğretim birinci sınıf yazı ögretimine etkisi. Pamukkale Üniversitesi Sosyal Bilimler Enstitüsü Dergisi, 6, 91-98.

Aram, D. ve Levin, I. (2001). Mother - child joint writing in low SES sociocultural factors, maternal mediation and emergent literacy. Cognitive Development, 16, 831-852. http://dx.doi.org/10.1016/S0885-2014(01)00067-3

Baker, C. (2013). Print-referencing: a key to interactive shared reading. Dimensions of Early Childhood, 41(1), 25-34.

Bay, Y. (2014). ABD'nin anasınıfı ve ilköğretim birinci sınıf okuma kitaplarının kelime öğretimi açısından incelenmesi. International Periodical For The Languages, Literature and History of Turkish or Turkic Volume, 9(12), 17-30. http://dx.doi.org/10.7827/TurkishStudies.7452

Baydık, B. (2003). Filizlenen okuryazarlık ve desteklenmesi. Ankara Üniversitesi Eğitim Bilimleri Fakültesi, 4(2), 77-89.

Baykan, S., Temel, Z. F., Ömeroğlu, E., Bulduk, S., Ersoy, Ö., Avc1, N. ve Turla, A. (1995). Ankara'da farklı sosyo-ekonomik düzeydeki 0-6 yaş çocuklarının gelişim durumlarının incelenmesi üzerine bir araştırma. Ankara: Milli Eğitim Bakanlığı.

Bayraktar, V. ve Temel, F. (2014). Okuma yazmaya hazırlık eğitim programının çocukların okuma-yazma becerilerine etkisi. Hacettepe Üniversitesi Eğitim Fakültesi Dergisi, 29(3), 8-22.

Bayraktar, V. ve Temel, F. (2015). Yazı farkındalığı becerileri. İçinde F. Temel (Ed.), Dil ve erken okuryazarlık (s. 63-88). Ankara: Hedef CS. 
Bredekamp, S. (2015). Çocuklara iletişimi öğretme: dil, okuryazarlık ve sanat. İçinde H. Z. İnan ve T. İnan (Ed.), Erken çocukluk eğitiminde etkili uygulamalar (s.374-409). Ankara: Nobel.

Büyüköztürk, Ş. (2012). Örnekleme yöntemleri. [Ders Notlar1]. http://w3.balikesir.edu.tr/ msackes/wp/wp-content/uploads/2012/03/BAY-FinalKonulari.pdf adresinden erişildi.

Büyüköztürk, Ş. (2014). Deneysel desenler öntest-sontest kontrol grubu desen ve veri analizi (4. Bask1). Ankara: Pegem.

Büyüktaşkapu, S. (2012). Okul öncesi eğitimi sürecinde çocuklara uygulanan aile destekli okumaya hazırlık programının ilkokuldaki okuma başarılarına etkisi. Kuram ve Uygulamada Ĕ̈itim Bilimleri Dergisi. 12(1), 301-316.

Cabell, S.Q., Justice, L.M., Konold, T.R. \& McGinty, A.S. (2011). Profiles of emergent literacy skills among preschool children who are at risk for academic difficulties. Early Childhood Education Journal, 26, 1-14. http://dx.doi.org/10.1016/j.ecresq.2010.05.003

Çelenk, S. (2003). İlkokuma-yazma öğretiminde kuluçka dönemi. Ankara Üniversitesi Ĕ̆itim Bilimleri Fakültesi Dergisi. 36(1-2), 75-80.

Deretarla Gül, E. ve Bal, S. (2006). Anasınıfı öğretmenlerinin okuma yazmaya hazırlık çalışmalarına ilişsin bakış açıları, sınıf içi kullanılan materyaller ve etkinlikler ile çocukların okuma yazmaya ilgilerinin incelenmesi. Çocuk Gelişimi ve Eğitimi Dergisi, $1(2), 33-51$.

Dolunay Sarıca, A. (2016). Etkileşimli kitap okuma programı (EKOP): kuramsal temelleri. İçinde C. Ergül (Ed.), Dil ve erken okuryazarlık becerilerinin geliştirilmesine yönelik etkileşimli kitap okuma programı (EKOP) (s.1-18). Ankara: Eğiten Kitap.

Edwards, C.P. ve Willis, L.M., (2000). Integrating visual and verbal literacies in the early childhood classroom. Early Childhood Education Journal, 27, 259-565. http://dx.doi.org/10.1023/B:ECEJ.0000003364.99437.5d

Er, S. (2016). Okul öncesi dönemde anne babaların etkileşimli hikaye kitabı okumalarının önemi. Başkent University Journal of Education, 3(2), 156-160.

Erdil, Z. (2010). Sosyoekonomik olarak risk altında bulunan çocuklara yönelik erken müdahale programları ve akademik başarı ilişkisi. Hacettepe Üniversitesi Să̆lık Bilimleri Fakültesi Hemşirelik Dergisi, 72-78.

Ergül, C., Akoğlu, G., Tufan, M. ve Kesiktaş, D. (Eylül 2011 - Eylül2013) - TÜBİTAK tarafından desteklenen "5-6 Yaş Çocukların Erken Okuryazarlık Becerilerinin Geliştirilmesine Yönelik Etkileşimli Kitap Okuma Programı’nın Etkililiğinin İncelenmesi” isimli proje. C. Ergül (Proje Yürütücü). http://uvt.ulakbim.gov.tr/uvt/index.php?keyword=etkile\%FEimli+kitap+okumaves_f= 1 vecommand $=$ TARAvethe $\_$page $=$vethe_ts $=$vevtadi $=$TPRJvecwid $=3 \#$ alt adresinden erişildi. 
Ergül, C., Karaman, G., Akoğlu, G., Tufan, M., Dolunay Sarıca, A. ve Bahap Kudret, Z. (2014). Okul öncesi öğretmenlerinin erken okuryazarlık kavramına ilişkin bilgi düzeyleri ve sinıf uygulamaları. Illköğretim Online, 13(4), 1449-1472. http://dx.doi.org/10.17051/io.2014.71858

Ergül, C., Akoğlu, G., Dolunay Sarıca, A., Tufan, M. ve Karaman, G. (2015). Anasınıflarında gerçekleştirilen birlikte kitap okuma etkinliklerinin etkileşimli kitap okuma bağlamında incelenmesi. Mersin Üniversitesi Eğitim Fakültesi Dergisi, 11(3), 603619.

Evans, M.A., Williamson, K. \& Pursoo, T. (2008). Preschoolers' attention top rint during shared book reading. Scientific Studies of Reading 12(1), 106-129. http://dx.doi.org/10.1080/10888430701773884

Gül, G. (2007). Okuryazarlık sürecinde aile katılımının rolü. Ankara Üniversitesi Ĕ̈gitim Bilimleri Fakültesi Özel Ĕ̈itim Dergisi, 8(1), 17-30.

Gürbüz, S. ve Şahin, F. (2014). Sosyal bilimlerde araştırma yöntemleri felsefe-yöntem-analiz. Ankara: Seçkin.

International Reading Association (IRA) ve National Association for the Education of Young Children (NAEYC). (1998). Learning to read and write: Developmentally appropriate practices for young children. National Association for the Education Young Children. In Young Children, 53(4), 30-46.

Işıtan, S. \& Akoğlu, G. (2016). Yazı farkındalığı becerilerinin resimli çocuk kitabı aracılığıyla değerlendirilmesi: güvenirlik ve geçerlik çalışması. International Periodical for the Languages, Literature and History of Turkish or Turkic, 11(3), 1333-1352. http://dx.doi.org/10.7827/TurkishStudies.9111

Justice, L.M. ve Ezell, H.K. (2002). Use of storybook reading to increase print awareness in at-risk children. American Journal of Speech-Language Pathology, 11, 17-29. http://ajslp.pubs.asha.org/ adresinden erişildi.

Justice, L. M. ve Pullen, P. C. (2003). Promising interventions for promoting emergent literacy skills: Three evidence-based approaches. Topics in Early Childhood Special Education, 23(3), 99-113.

Kandır, A. ve Koçak Tümer, N.B. (2013). Farklı sosyo-ekonomik düzeydeki beş-altı yaş çocuklarının erken öğrenme becerilerinin incelenmesi. Sosyal Politika Çalışmaları, 7(30), 45-60.

Karaman, G. (2013). Erken okuryazarlık becerilerini değerlendirme aracı'nın geliştirilmesi, geçerlik ve güvenirlik çalışması. (Yayımlanmamış Doktora Tezi). Gazi Üniversitesi Eğitim Bilimleri Enstitüsü, Ankara.

Karaman, G. (2015). Erken okuryazarlık becerilerinin tarihsel gelişimi, kuramsal temelleri ve kapsamı. İçinde Z. F. Temel (Ed.), Dil ve erken okuryazarlık (s.10-31). Hedef CS. 
Lonigan, C. J., Anthony, J. L., Bloomfield, B. G., Dyer, S. M. ve Samwel, C. S. (1999). Effects of two shared-reading interventions on emergent literacy skills of at-risk preschoolers. Journal of Early Intervention, 22(4), 306-322.

Lonigan, C. J. (2006). Development, assessment, and promotion of preliteracy skills. Early $\begin{array}{llll}\text { Education } \text { and } & \text { 17(1), }\end{array}$ htpp://dx.doi.org/10.1207/s15566935eed1701_5

Milli Eğitim Bakanlığ1 Temel Eğitim Genel Müdürlüğü. (2013a). Okul öncesi eğitim programı. Ankara: Milli Eğitim Bakanlığı.

Milli Eğitim Bakanlığı Temel Eğitim Genel Müdürlüğü. (2013b). Okul Öncesi Ĕ̆itim Programı Ile Bütünleştirilmiş Aile Destek Eğitim Rehberi. Ankara: Milli Eğitim Bakanlığ 1 .

Opel, A., Ameer, S. S. \& Aboud, F. E. (2009). The effect of preschool dialogic reading on vocabulary among rural Bangladeshi children. International Journal of Educational Research, 48, 12-20. http://dx.doi.org/10.1016/j.ijer.2009.02.008

Özbek Ayaz, C. (2015). Ailelerin, okul öncesi dönemdeki çocuklarının okuryazarlık becerilerini desteklemek için kullandıkları okuryazarlık uygulamalarının incelenmesi: Tekirdăg ili örneği. (Yayımlanmamış Yüksek Lisans Tezi). Çanakkale Onsekiz Mart Üniversitesi Eğitim Bilimleri Enstitüsü, Çanakkale.

Sarıca, A. D., Ergül, C., Akoğlu, G., Deniz, K. Z., Karaman, G., Bahap-Kudret, Z. ve Tufan, M. (2014). Ev erken okuryazarlık ortamı ölçeği - EVOK: Geçerlik ve güvenirlik çalışması. Uluslararası Eğitim Bilimleri Dergisi, 6(2), 444-459. http://dx.doi.org/10.15345/iojes.2014.02.016

Şahin, F. (2015). Erken okuryazarlık gelişimini destekleyici unsurlar. İçinde F. Temel (Ed.), Dil ve erken okuryazarlık (s.105-125). Ankara: Hedef CS.

Şimşek Bekir, H. ve Temel, Z. F. (2006). Almanya'da okul öncesi eğitim kurumlarına devam eden 5-6 yaş grubu Türk çocuklarına uygulanan dil eğitim programının dil gelişim düzeyine etkisi. Gazi Üniversitesi Endüstriyel Sanatlar Ĕ̌itim Fakültesi Dergisi, 18, 14-27.

Şimşek, Ö. (2011). 60-72 aylık çocukların yazı farkındalığı ve yazmaya hazırlık becerilerinin gelissiminde okuma yazmaya hazırlık programının etkisinin incelenmesi. (Yayımlanmamış Doktora Tezi). Gazi Üniversitesi Eğitim Bilimleri Enstitüsü, Ankara.

Şimşek Çetin, Ö. ve Alisinanoğlu, F. (2013). Okuma yazmaya hazırlık programının okul öncesi dönemdeki çocukların yazı farkındalığına etkisinin incelenmesi. Uluslararası Ĕ̈itim Bilimleri Dergisi, 5(1), 160-173.

Şimşek Çetin, Ö. (2014). Okul öncesi dönemdeki çocukların yazı farkındalığı ve yazmaya hazırlık becerilerinin incelenmesi. Kuramsal Eğitim Bilimleri Dergisi, 7(3), 342-360. http://dx.doi.org/10.5578/keg.7036 
Uyanık, Ö. ve Kandır, A. (2010). Okul öncesi dönemde erken akademik beceriler. Kuramsal Ĕ̈itimbilim Dergisi, 3(2), 118-134.

Whitehurst, G. J. ve Lonigan, C. J. (1998). Child development and emergent literacy. Child Development, 69(3), 848-872.

Yazıc1, Z. ve Temel, Z. F. (2011). İkidilli ve tek dilli çocuklarda dil gelişimi okuma olgunluğu ilişkisi. Mehmet Akif Ersoy Üniversitesi Ĕ̌itim Fakültesi Dergisi, 22, 145-158.

Yıldız, M., Ataş, M., Aktaş, N., Yekeler, A. D. ve Dönmez, T. (2015). Çocuklar ne yazıyor? Okul öncesi dönemde yazı algısının gelişimi. International Periodical for The Languages, Literature and History of Turkish or Turkic, 10(3), 1121-1142. http://dx.doi.org/10.7827/TurkishStudies.7844 